\title{
THE EFFECTS OF GLOBAL MONETARY POLICY ON FOREIGN DEBT AND DEBT CRISIS
}

\author{
Dušan Aničić1, Jugoslav Aničić ${ }^{2}$ Nataša Simićn ${ }^{3}$, Gordana Bejatovićc \\ ${ }^{1,2,3,4}$ University Union - Nikola Tesla, Faculty of Economics and Finance, Belgrade, Serbia \\ anicic.dusan@yahoo.com, ajugoslav@yahoo.com,nsimic68@gmail.com, \\ gordana.bejatovic@yahoo.com
}

\section{Original Scientific Paper doi:10.5937/jouproman7-19855}

\begin{abstract}
Economic policy of western developed countries is based on Washington agreement principles - liberalization, deregulation and privatization, with as little as possible participation of state in economic movements. Such policy is supported by the biggest financial institutions, from the World Bank, IMF, US Federal Reserve, European banks and other. Although such policy gave a range of bad results in practice, its basic postulates are still in power. On the other hand, global economic crisis lead to the fact that many highly developed countries have problems of high foreign indebtedness. This problem is even more complex in countries in development and, so called, transitional countries, where Serbia belongs, which, by the relation of foreing debt towards GDP belogns to a group of countries with an intermediate debt, according to the World bank's criteria.
\end{abstract}

Key words: monetary policy, foreign debt, financial institutions, current deficit

\section{Introduction}

Dominant direction of economic policy in developed countries since $1980 \mathrm{~s}$ is monetarism, and in that period neoliberal concept of economy, which advocates state's role reduction and sharp measures of fiscal savings, is being developed. Monetarism is based on the reduction of direct and an increase of indirect taxes, as well as on an increase of interest rate in order to limit money supply growth and reduce inflation. Limitations of public sector spending are introduced and social insurance expenses are cut down. Such policy is supported by IMF, World Bank, European Investment bank and other most important world's financial institutions. Although such policy had very bad results in many countries, it is still based on the principles of, so called, Washington consensus.

High foreign debt of most developed countries in the world, as well as of countries in development and insufficiently developed countries, is a characteristic in modern economic surrounding. The question of debt sustainability is important, because different countries have different competitiveness of economy, so the problems of foreign debt are also different among them. For example, according to Eurostat data, at the end of 2017 indebtedness in European Union is, on average, $81,6 \%$ (relation foreign debt towards GDP). The biggest economies also have a high level of indebtedness, for example, Germany 64,1\%, France 97,0\%, Italy $131,8 \%$, Spain $98,3 \%$. Greece with $178,6 \%$ and Portugal with $125,7 \%$ are among countries which have the highest indebtedness. Republic of Serbia is in a group of countries with an intermediate indebtedness, but having in mind unfavorable country's economic structure, foreign debt control will be one of the biggest challenges of economic policy in future. 


\section{Genesis of international monetary policy and current problems}

Chronology of international monetary system's development is, in literature, usually followed through these periods (Filipovic, Petrovic, 2015):

- Gold standard period (1870 1914);

- Gold foreign currency (dollar) standard in the period between two world wars, 1918-1939;

- Bretonwood rules validity period, from 1944 to 1973;

- International monetary system after the validity of Bretonwood agreement (after 1973).

1870 is considered to be the start of gold standard period when gold, as a general measure of value, was accepted by Great Britain, USA, Germany and other countries. Fixed foreign exchange rate was dominant in the gold standard period. International monetary system based on gold standard implied an existence of unrestricted freedom of gold movements and that monetary authorities, at any moment, must convert currencies into gold.

Gold standard functioned all the way to the start of World War I, and it was characterized by low inflation rate, stability of prices and stable economic development. After the end of World War I, European countries had demolished economies, so they resorted to inflated financing. On the other hand, USA retained strong economy which instantly set it up in a position of global financial leader.

Stumbled world economy in the conditions of violated internal and external imbalance could not find a way out in a rigid gold standard. Inflation growth crashed general confidence that monetary authorities will conduct obligatory conversion of currencies into gold. As a consequence of that, gold standard was abandoned and a switch to fluctuating foreign exchange rate was made. After that, there were often devaluations of currencies which caused more often introduction of customs' instruments of control and protection (quotas, tariffs), so it was a retrograde period in international trade and investments.

After World War II, USA retained and strengthened its position of world's financial and economic leader. Most other countries had chronic balance of payments deficit and nonconvertible currencies. In such circumstances, monetary system which would enable full employment, prices' stability and external balance without introduction of restrictions in international trade, should have been designed. As a solution of mentioned problems, White's plan, which was a modification of gold standard, was accepted. The value of gold was fixed in relation to dollar (35 dollars per ounce of gold) and only FED had an obligation to convert dollars into gold. All other countries determined the value of its currencies in relation to dollar, and their foreign-exchange reserves were kept in the form of gold and dollars which they could sell to FED for gold at the official price.

At the end of 1950s most European countries established convertibility of its currencies and that opened a possibility of private capital movement, as well as for an emergence of speculative capital movements and financial crisis. By the doubt into credibility of USA's central bank and convertibility of dollar into gold, many countries demanded conversion of dollar into gold. Due to high unemployment rate and a high balance of payments deficit, USA in 1971 declared that they will not automatically convert dollars into gold any more. Price of gold on free market started to make pressure on official exchange rate. 
After devaluation of $10 \%$ in February of 1973, Japan and countries of then European Economic Community decided to let its currencies to "swim", which marked a start of Bretonwood system falling apart.

Dominant economic policy direction in USA and Great Britain at the beginning of 1980s was monetarism. It assumes that markets strive towards a balance and that deviations are accidental, and at the same time neoliberal concept of economy, which advocates state's role reduction and sharp fiscal savings measures, was developed. Monetarism is based on reduction of direct and an increase of indirect taxes, as well as on interest rate increase in order to limit money supply's growth and reduce inflation. Restrictions of public sector spending were introduced and social insurance expenses were cut down.

At the beginning of 2000s, USA conducted expansive fiscal policy (low taxes and budget spending increase) and a policy of cheap money based on low referent interest rate. That was a flywheel of US' economy development so investments in the period between 2000 and 2005 were up to 2 billion US dollars on a daily basis (Trichet, 2005). Also, USA became the main recipient of world savings while Asian countries (first of all China) became creditors of world's strongest economy (Summers, 2006). Monetarists do not consider current balance deficit to be a direct threat to American economy, nor a cause of global imbalance of balance of payments (Perelstein, 2009).

During recent years, more and more economists consider US' current balance deficit to be unsustainable and that it could have bad consequences for world's economy. Krugman was one of the first economists which warned that deficit of current balance of USA could lead to dollar crisis, where a high level of foreign debt means much bigger capital losses for investors and big macroeconomic problems for USA (Krugman, 2007). If economy of USA is indebted in favor of consumpiton instead of investments, there will come a moment when dollar will no longer be a good investment.

According to Stiglitz (2004), world's financial institutions did not give an answer to developmental problems of countries in development, so it is necessary to offer new solutions which enable economic development in joint action of state and market. Many countries in development and in transition, in conduction of its monetary (and entire economic) policy rely on postulates of International Monetary Fund and the World bank, because they are oftentimes forced to use loans from these institutions. Basic premises on which the policy of these institutions is based are liberalization, deregulation and privatization, hence as small as possible role of the state in economic life. Although this policy had bad results in a large number of countries, IMF still insists on its consistent application, without taking into consideration specificities of the country in which it is applied. Examples are countries that conducted IMF's reforms, and whose foreign debt is still enormous and they are in big financial difficulties (Greece, Ukraine, Argentina and other).

\section{Indebtedness and foreign debt structure of the Republic of Serbia}

Foreign debt of a country represents debt of all sectors towards foreign countries (enterprises, banks, state). World bank and IMF, in 2004, introduced a new standard of reporting on foreign indebtedness of individual countries in order to ensure an international comparability of data on foreign debt amounts. 
This standard is based on gross principle of foreign debt and includes current and unconditional liabilities which demand payments of principal and/or interest which debtor resident owes to a nonresident at a certain moment.

The most important indicator of indebtedness of a country is a ratio of entire foreign debt to gross domestic product. According to the World bank criteria, countries are, according to the size of this indicator, divided into three groups:

- Countries with small debt - ratio of foreign debt to GDP less than $48 \%$,

- Countries with intermediate debt ratio of foreign debt to GDP between $48 \%$ and $80 \%$,

- Countries with high debt - ratio of foreign debt to GDP above $80 \%$.

Second important indicator of country's indebtedness is ratio of foreign debt to export of goods and services. According to the World Bank criteria, countries are, by the size of this indicator divided into three groups:

Drugi važan pokazatelj zaduženosti zemlje je odnos spoljnog duga prema izvozu roba i usluga. Prema kriterijumima Svetske banke zemlje se po veličini ovog pokazatelja dele u tri grupe i to:

- Countries with small debt - ratio of foreign debt to export less than $132 \%$,

- Countries with intermediate debt ratio of foreign debt to export between $132 \%$ and $220 \%$,

- Countries with high debt - ratio of foreign debt to export above $220 \%$.

Contemporary economic surrounding is characterized by, among other, high foreign debt of most developed countries in the world, as well as countries in development and insufficiently developed countries. So today, even the most developed countries in the world, such as USA, Japan, Germany, France and other, have exceptionally high foreign debt, which means that their development was based not only on domestic accumulation, but on borrowing of external means as well. The question of foreign debt sustainability is important, that is capability of countries to service their obligations in foreseen terms, without endangerment of their future development. Different countries have different productivity, unemployment rate, GDP per capita, namely competitiveness, therefore they can differently answer to the problems of their foreign debt.

According to Eurostat data, at the end of 2017 indebtedness in EU is, on average, around $81,6 \%$. The biggest economies also have high level of indebtedness, for example Germany 64,1\%, France 97,0\%, Italy $131,8 \%$, Spain 98,3\%. Among countries with highest indebtedness are Greece with 178,6\% and Portugal with $125,7 \%$, while the lowest indebtedness have Czech Republic (34,6\%), Denmark (36,4\%), Luxemburg (23,0\%). Countries in our surrounding - Slovenia 73,6\%, Croatia 78,0\%, Romania 35\%, Bulgaria $25,4 \%$, etc.

From data in Table 3 we can see Serbia's foreign debt structure, in which international financial organizations participate with around $25 \%$, and the largest creditors are European Investments Bank, European Bank for Reconstruction and Development, International Monetary Fund, and also a significant part of the debt is contained in euro-bonds (over 4.800 million euro). Foreign exchange reserves of the Republic of Serbia on 31 December 2017 amount to 9.962 million euro, according to NBS' data (2018). 
Table 3: Structure of foreign debt of the Republic of Serbia towards creditors, on 31 December 2016

(in millions of euros)

\begin{tabular}{|l|r|}
\hline I Long-term and medium-term debt & $25.782,7$ \\
\hline International financial organizations & $6.693,1$ \\
\hline Foreign governments, their agencies and development banks & $4.924,7$ \\
\hline Euro-bonds & $4.808,0$ \\
\hline Other creditors & 9.356 .9 \\
\hline II $\quad$ Short-term debt & 705,4 \\
\hline Total ( I + II ) & $26.488,1$ \\
\hline
\end{tabular}

Source: National Bank of Serbia, Statistical Bulletin - Decembar 2017

According to data from Table 4, we can see that public sector makes almost $60 \%$ of total foreign debt of the country, while the rest is private sector's debt - enterprises, banks, individuals. Low participation of short-term debt in total debt is a positive

Table 4: Foreign debt of the Republic of Serbia towards debtors, on 31 December 2016

(in millions of euros)

\begin{tabular}{|l|r|}
\hline I Long-term debt & $25.811,8$ \\
\hline Public sector & $15.679,7$ \\
\hline Private sector & $10.132,1$ \\
\hline II Short-term debt & 676,2 \\
\hline Public sector & - \\
\hline Private sektor & 676,2 \\
\hline Total ( I + II ) & $26.488,1$ \\
\hline
\end{tabular}

Source: National Bank of Serbia, Statistical Bulletin - Decembar 2017

Growth rates of GDP in Serbia after economic crisis from 2008 are very low, in comparison with developed countries, as well as with countries in surrounding. Similarly, whole this period is characterized by deficit of foreign trade, along with unfavorable structure of export and import. Such trends last for too long which does not allow country to free itself from dependence on foreign finance sources and high indebtedness, and by that all negative consequences that high indebtedness brings along. circumstance: entire short-term debt refers to private sector (banks - 590,1 million euro, enterprises - 86,2 million euro) which points out favorable term-structure of indebtedness, that is liquidity. 
Today, even the biggest world's economies have high foreign debt (USA, France, Italy, Japan). Importatn question is debt's sustainability, that is economy structure which is based on export which will enable servicing of debt. Indebtedness can have positive effects i fasten economic growth if borrowed means are efficiently used, but it can slow it down as well, if the loans are used to finance consumption or budget's deficit. Core of successful economic policy is that indebtness increase leads to growth of GDP, export, competitiveness, as well as to unemployment reduction of its population.

\section{Literature}

Krugman, P., (2007) Will There Be a Dollar Crisis? Economic Policy

Narodna banka Srbije (2018) Statistički bilten decembar 2017., Beograd

Narodna banka Srbije (2018) Međunarodna investiciona pozicija Republike Srbije, Beograd

Perelstein, J., (2009), Macroeconomic Imbalances in the States and Their Impact on the International Financial System, Levy Institute, New York

Filipović, S., Petrović, P., (2015) Pozicioniranje privrede u globalnom ekonomskom okruženju, Ekonomski institut, Beograd

Stiglitc, J., E., (2004) The Post-Washington Consensus, The Initiative for Policy Dialogue

Summers, L., (2006) Reflections on Global Account Imbalances and Emerging Markets Reserve Accumulation, L.K. Jha Memorial Lecture, Reserve Bank of India, India

Trichet, J., (2005) Reflections on the International Financial System, Speech by Jean-Claude Trichet, President of the ECB. Bundesbank Lecture, Berlin

www.ec.europa.eu/eurostat, pristup sajtu 10.09.2018. godine 